\title{
Nautilia abyssi sp. nov., a thermophilic, chemolithoautotrophic, sulfur- reducing bacterium isolated from an East Pacific Rise hydrothermal vent
}

\author{
Karine Alain ${ }^{1,{ }^{*}}$, Nolwenn Callac ${ }^{1}$, Marianne Guégan ${ }^{1}$, Françoise Lesongeur ${ }^{1}$, Philippe \\ Crassous $^{2}$, Marie-Anne Cambon-Bonavita ${ }^{1}$, Joël Querellou ${ }^{1}$ and Daniel Prieur ${ }^{1}$
}

\footnotetext{
${ }^{1}$ UMR6197, Laboratoire de Microbiologie des Environnements Extrêmes, IUEM, Technopôle Brest-Iroise, F29280 Plouzané, France

${ }^{2}$ Laboratoire Environnement Profond, Ifremer EEP/LEP, BP 70, F-29280 Plouzané, France
}
*: Corresponding author : Karine Alain, Phone number : +33-(0)2-98-49-88-53 Fax : +33-(0)2-98-49- 87-05, email address : Karine.Alain@univ-brest.fr

\begin{abstract}
:
A novel strictly anaerobic, thermophilic, sulfur-reducing bacterium, designated $\mathrm{PH} 1209^{\top}$, was isolated from an East Pacific Rise hydrothermal vent $\left(1^{\circ} \mathrm{N}\right)$ sample and studied using a polyphasic taxonomic approach. Cells were Gram-negative, motile rods (approx. 1.60x0.40 $\mu \mathrm{m}$ ) with a single polar flagellum. Strain $\mathrm{PH} 1209^{\top}$ grew at temperatures between 33 and $65^{\circ} \mathrm{C}$ (optimum $60{ }^{\circ} \mathrm{C}$ ), from pH 5.0 to 8.0 (optimum 6.0-6.5), and between 2 and $4 \%$ (w/v) $\mathrm{NaCl}$ (optimum $3 \%$ ). Cells grew chemolithoautotrophically with $\mathrm{H}_{2}$ as an energy source, $\mathrm{S}^{0}$ as an electron acceptor and $\mathrm{CO}_{2}$ as a carbon source. Strain $\mathrm{PH} 1209^{\top}$ was also able to use peptone and yeast extract as carbon sources. The $\mathrm{G}+\mathrm{C}$ content of the genomic DNA was $35 \mathrm{~mol} \%$. Phylogenetic analyses based on 16S rRNA gene sequencing showed that strain $\mathrm{PH}_{120{ }^{\top}}$ fell within the order Nautiliales, in the class Epsilonproteobacteria. Comparative 16S rRNA gene sequence analysis indicated that strain $\mathrm{PH} 1209^{\top}$ belonged to the genus Nautilia and shared 97.2 and $98.7 \%$ 16S rRNA gene sequence identity, respectively, with the type strains of Nautilia lithotrophica and Nautilia profundicola. It is proposed, from the polyphasic evidence, that the strain represents a novel species, Nautilia abyssi sp. nov.; the type strain is $\mathrm{PH} 1209^{\top}\left(=\mathrm{DSM} 21157^{\top}=\mathrm{JCM} 15390^{\top}\right)$.
\end{abstract}

Epsilonproteobacteria are widely distributed in marine and terrestrial ecosystems (Campbell et al., 2006). They are particularly common and abundant in $30-70^{\circ} \mathrm{C}$ areas of deep sea hydrothermal vents, as indicated by their prevalence in the clone libraries (Polz \& Cavanaugh, 1995; Longnecker \& Reysenbach, 2001; Lopez-Garcia, 2002; Alain et al., 2004), the results of fluorescence in situ hybridization (Moussard et al., 2006) and the isolation of several representatives (Alain et al., 2002; Miroshnichenko et al., 2002; Inagaki et al., 2003; Takai et al., 2003, 2005, 2006; Voordeckers et al., 2005). Within this singular ecosystem, Epsilonproteobacteria are retrieved in various habitats, thriving (i) as free-living organisms on chimney structures, within vent plumes and in sediments, (ii) as epi- or endosymbionts of hydrothermal invertebrates, or (iii) embedded in mats on the surfaces of chimney rocks or animals. Cultured isolates from deep sea vents are all mesophilic to thermophilic chemolithoautotrophs coupling the oxidation of hydrogen or sulphur compounds to the reduction of nitrate, sulfur compounds or oxygen (Takai et al., 2003; Campbell et al., 2006). Because of their abundance and metabolic abilities, Epsilonproteobacteria are likely to be key players of the carbon, sulfur and nitrogen biogeochemical cycling at deep-sea vents. Two orders are currently described within the class Epsilonproteobacteria Garrity et al. 2006 (Validation List n¹07, Garrity et al., 2005), namely the Nautiliales (Miroshnichenko et al., 2004) and the Campylobacterales Garrity et al. 2006 (Validation List $n^{\circ} 107$, Garrity et al., 2005). The order Nautiliales comprises the genera Nautilia (Miroshnichenko et al., 2002), Caminibacter (Alain et al., 2002) and Lebetimonas (Takai et al., 2005) which are exclusively composed of thermophilic strains isolated from 
deep-sea hydrothermal vents and which have been found in association with invertebrates or with chimney edifices. At present, the genus Nautilia is composed of two species, Nautilia lithotrophica (Miroshnichenko et al., 2002) and Nautilia profundicola (Smith et al., 2008). Both strains are strictly anaerobic sulfurreducing mixotrophs able to grow on hydrogen and carbon dioxide, or alternatively on formate.

In this study, a novel marine bacterium belonging to the genus Nautilia is described. Based on the results of a polyphasic taxonomic analysis, the strain $\mathrm{PH} 1209^{\mathrm{T}}$ represents a novel species, Nautilia abyssi sp. nov.

In April-May 2002, during the PHARE oceanographic cruise, fragments of active hydrothermal chimney rocks covered with colonies of the tubeworm polychaete Alvinella spp. were collected from 2620m depth at the Elsa vent field, on the East Pacific Rise $13^{\circ} \mathrm{N}\left(12^{\circ} 48^{\prime} \mathrm{N}, 103^{\circ} 56^{\prime} \mathrm{W}\right)$. Sample collection, subsampling and storage procedures were as described elsewhere (Alain et al., 2004). One subsample collected on the Ph01 chimney was used to inoculate series of media, including KA22 medium (Alain et al., 2002), and incubated at $60^{\circ} \mathrm{C}$ under a gas phase of $\mathrm{H}_{2} / \mathrm{CO}_{2}(80 / 20 ; 200 \mathrm{kPa})$. After $24 \mathrm{~h}$ incubation, dense populations of short, rod-shaped, motile cells were observed and purified by repeated dilution to extinction series. One isolate, referenced as strain $\mathrm{PH} 1209^{\mathrm{T}}$, is described in this publication. Purity of this isolate was confirmed routinely by microscopic examination and by repeated partial sequencing of the $16 \mathrm{~S}$ rRNA gene using several primers. Stock cultures were stored at $-80^{\circ} \mathrm{C}$ in KA22 medium supplemented with $5 \%$ (v/v) DMSO.

Morphological characteristics of the cells were determined by light microscopy (Olympus CX40) and by scanning electron microscopy (FEI Quanta 200). Cells of strain PH1209 ${ }^{\mathrm{T}}$ were Gram-negative, straight rods of 1.05-2.21 $\mu \mathrm{m}$ in length (mean $1.63 \mu \mathrm{m} \pm 0.34, \mathrm{n}=11$ ) and $0.30-0.51 \mu \mathrm{m}$ in width (mean $0.39 \pm 0.05, \mathrm{n}=11$ ) in the mid-exponential phase of growth (see Supplementary Fig. S1 in IJSEM online). They occurred mainly singly and were highly motile by a polar flagellum (Fig. S1A). Division was by constriction (Fig. S1B). Formation of spores was never observed.

The physiological characterization of the novel isolate was carried out in a basal medium referenced as "NPKsalts" and containing (per liter): $0.33 \mathrm{~g} \mathrm{NH}_{4} \mathrm{Cl}, 0.33 \mathrm{~g} \mathrm{KCl}, 0.33 \mathrm{~g} \mathrm{CaCl}_{2} \cdot 2 \mathrm{H}_{2} \mathrm{O}, 0.33 \mathrm{~g} \mathrm{MgCl}_{2} \cdot 6 \mathrm{H}_{2} \mathrm{O}$, $25 \mathrm{~g} \mathrm{NaCl}, 1.0 \mathrm{~g} \mathrm{NaNO}_{3}, 1.95 \mathrm{~g}$ MES buffer (Sigma) and $1 \mathrm{mg}$ resazurin (Sigma). Its $\mathrm{pH}$ was adjusted to 
6.0. Once prepared, this medium was autoclaved and then cooled to room temperature under a stream of $\mathrm{O}_{2^{-}}$ free $\mathrm{N}_{2}$ gas. Concentrated anaerobic filter-sterilized solutions of vitamins and trace elements were added to the medium after autoclaving. Then, just before inoculation, $\mathrm{Na}_{2} \mathrm{~S} .9 \mathrm{H}_{2} \mathrm{O}, \mathrm{KH}_{2} \mathrm{PO}_{4}$ and elemental sulfur were provided from sterile stocks, to final concentrations of $0.04 \%(\mathrm{w} / \mathrm{v}), 20 \mathrm{mM}$ and $1.2 \%(\mathrm{w} / \mathrm{v})$, respectively. Unless stated otherwise, the experiments were carried out anaerobically, under a gas phase of $\mathrm{H}_{2} / \mathrm{CO}_{2}$ $(80 / 20 ; 200 \mathrm{kPa})$, and incubation were done in the dark and under agitation. Growth was routinely monitored by direct cell counting using a modified Thoma chamber (depth $10 \mu \mathrm{m}$ ), or by counting after fixation with $1 \%(\mathrm{v} / \mathrm{v})$ glutaraldehyde and storage at $-20^{\circ} \mathrm{C}$. Growth rates were calculated using linear regression analysis of four to nine points along the logarithmic portions of the resulting growth curves. The determination of the temperature range for growth was tested over the range $30-80^{\circ} \mathrm{C}$ (i.e. $30,33,37,45,50$, $\left.55,60,65,70,75,80^{\circ} \mathrm{C}\right)$. No growth was observed at $30^{\circ} \mathrm{C}, 70^{\circ} \mathrm{C}$ and above. The novel isolate grew from 33 to $65^{\circ} \mathrm{C}$, with an optimum growth rate at $60^{\circ} \mathrm{C}$ (see Supplementary Fig. S2A in IJSEM online). The pH range for growth was tested at $60^{\circ} \mathrm{C}$ in basal medium buffered and adjusted to the required initial $\mathrm{pH}$ as described elsewhere (Alain et al., 2002). Growth was observed from $\mathrm{pH} 5.0$ to $\mathrm{pH} 8.0$, the optimum being around $\mathrm{pH}$ 6.0-6.5 (Fig. S2B). No growth was observed at $\mathrm{pH} 4.0$ and $\mathrm{pH}$ 8.5. Salt tolerance was tested at $60^{\circ} \mathrm{C}$ in NPKsalts medium prepared with various concentrations of $\mathrm{NaCl}(0,0.5,1,2,3,4,5,6,8$ and $10 \%$ w/v). Growth was observed at salt concentrations ranging from 2 to $4 \%(w / v) ~ N a C l$, the optimum salinity being around 3\% (Fig. S2C). No growth was observed at 1 and 5\% (w/v) NaCl. Under optimal growth conditions, the generation time of strain $\mathrm{PH} 1209^{\mathrm{T}}$ was around 120 minutes.

Strain $\mathrm{PH} 1209^{\mathrm{T}}$ was a strictly anaerobic, chemolithoautotrophic bacterium that used sulfur, hydrogen and carbon dioxide as respective primary electron acceptor, electron donor and carbon source. Its ability to use alternative electron acceptors was tested by adding colloidal sulfur (Sigma Aldrich) $\left(5 \mathrm{~g} \mathrm{l}^{-1}\right)$, L-cystine (12 g $\left.\mathrm{l}^{-1}\right)$, sulfite $(1 \mathrm{mM})$, thiosulfate $(20 \mathrm{mM})$, sulfate $(20 \mathrm{mM})$, nitrate $(10 \mathrm{mM})$, nitrite $(1 \mathrm{mM})$ and oxygen $(1 \%$ v/v) to nitrate and sulfur-depleted media, under an atmosphere of $\mathrm{H}_{2} / \mathrm{CO}_{2}(80 / 20 ; 200 \mathrm{kPa})$. Quantitative determination of hydrogen sulfide was as described elsewhere (Cord-Ruwisch, 1985). The novel isolate was found to grow with elemental sulfur and colloidal sulfur, with concomitant production of $\mathrm{H}_{2} \mathrm{~S}$, but did not grow when L-cystine, sulfite, thiosulfate, sulfate, nitrate, nitrite and oxygen were used as electron acceptors. 
To examine possible carbon sources other than $\mathrm{CO}_{2}$, a variety of organic carbon sources were tested in the presence of sulfur, under an atmosphere of $\mathrm{H}_{2} 100 \%(200 \mathrm{kPa})$. Formate $(10 \mathrm{mM})$, acetate $(10 \mathrm{mM})$, butyrate $(10 \mathrm{mM})$, propionate $(10 \mathrm{mM})$, methanol $(0.5 \% \mathrm{v} / \mathrm{v})$, pyruvate $(10 \mathrm{mM})$, lactate $(0.5 \% \mathrm{v} / \mathrm{v})$, fumarate $(10 \mathrm{mM})$, glucose $(10 \mathrm{mM})$, peptone $\left(2 \mathrm{~g} \mathrm{l}^{-1}\right)$ and yeast extract $\left(2 \mathrm{~g} \mathrm{l}^{-1}\right)$ were tested as potential substrates. Heterotrophic growth (with concomitant $\mathrm{H}_{2} \mathrm{~S}$ production) was observed exclusively with yeast extract and peptone and was probably the result of the decarboxylation of amino acids. The growth rates with yeast extract and peptone were in the same order of magnitude than the one measured with carbon dioxide as carbon source. To test for the capability of the strain to use electron donors other than molecular hydrogen, the strain was cultivated under a gas phase of $\mathrm{N}_{2} / \mathrm{CO}_{2}(80 / 20,200 \mathrm{kPa})$ in the presence of formate $(20 \mathrm{mM})$, acetate $(20 \mathrm{mM})$, methanol $0.5 \%(\mathrm{v} / \mathrm{v})$ and yeast extract $\left(2 \mathrm{~g} \mathrm{l}^{-1}\right)$, and with sulfur as a terminal electron acceptor. No growth was observed with the alternative energy sources, indicating that strain PH1209 ${ }^{\mathrm{T}}$ was a strict hydrogen-oxidizer. The nitrogen sources for growth were also examined in a nitrogendepleted medium. The novel isolate was found to grow on organic and inorganic nitrogen sources. Significant growth was observed when $\mathrm{NH}_{4} \mathrm{Cl}(20 \mathrm{mM})$, glutamate $(10 \mathrm{mM})$, yeast extract $\left(0.2 \mathrm{~g} \mathrm{l}^{-1}\right)$, tryptone $\left(0.2 \mathrm{~g} \mathrm{l}^{-1}\right)$, gelatin $(0.05 \% \mathrm{v} / \mathrm{v})$ and urea $(0.05 \% \mathrm{v} / \mathrm{v})$ were provided as sole nitrogen source.

Antibiotic resistance was tested in the presence of a variety of antibiotics from different chemical nature and with different targets and mechanisms. The resistance to vancomycin, streptomycin, chloramphenicol, kanamycin, rifampicin, penicillin, ampicillin and tetracycline was investigated at concentrations of 10, 25, 50 and $100 \mu \mathrm{g} \mathrm{ml}^{-1}$. When the antibiotic was diluted in ethanol (chloramphenicol) or DMSO (rifampicin), the same volume of solvent was added to control cultures. All antibiotics were added aseptically before inoculation and the cultures were incubated at $60^{\circ} \mathrm{C}$ for one week. Strain PH1209 $9^{\mathrm{T}}$ was found to be sensitive to vancomycin, streptomycin, chloramphenicol, penicillin, ampicillin and tetracycline, all at $10 \mu \mathrm{g} \mathrm{ml}^{-1}$. It grew in the presence of $10 \mu \mathrm{g} \mathrm{ml}^{-1}$ rifampicin and $25 \mu \mathrm{g} \mathrm{ml}^{-1}$ kanamycin, but was sensitive to higher concentrations of these two antibiotics.

The genomic DNA G+C content was determined, by the Identification Service of the DSMZ (Deutsche Sammlung von Mikroorganismen und Zellkulturen GmbH, Braunschweig, 
Germany), by HPLC analysis of deoxyribonucleosides as described by Mesbah et al. (1989). The G+C content of strain $\mathrm{PH} 1209^{\mathrm{T}}$ was $35 \mathrm{~mol} \%$.

The almost complete $16 \mathrm{~S}$ rRNA gene (1369 bp) of the strain was double-strand sequenced, as described elsewhere (Alain et al., 2002). This sequence was compared to those in available databases by use of the BLAST program (Altschul et al., 1990) and then aligned to its nearest neighbours using the CLUSTALX program (Thompson et al., 1997). Alignments were refined manually using the SEAVIEW program (Galtier et al., 1996). Distance matrixes were calculated with the Lasergene 6 version software. Phylogenetic trees were constructed by the PHYLIP (PHYlogeny Inference Package) version 3.63 software (http://evolution.genetics.washington.edu/phylip/getme.html) on the basis of evolutionary distance (neighbour-joining method with Jukes and Cantor corrections) (Saitou and Nei, 1987) and maximum likelihood (Felsenstein, 1981). The robustness of the inferred topologies was assessed by bootstrap analyses based on 1000 bootstrap resamplings for the neighbour-joining and 100 replications for the maximum likelihood method (Felsenstein, 1985). Comparison of the 16S rRNA gene sequence with sequences of Bacteria indicated that the novel isolate belonged to the class Epsilonproteobacteria Garrity et al. 2006 (Validation List n ${ }^{\circ} 107$, Garrity et al., 2005) and more especially to the order Nautiliales (Miroshnichenko et al., 2004). Within this lineage that is composed exclusively of taxa from deep-sea hydrothermal vents, the novel isolate was found to be most closely related to a group of moderately thermophilic sulfur reducers, all isolated from the EPR $13^{\circ} \mathrm{N}$ like PH1209 $9^{\mathrm{T}}$ (Fig. 1). The novel isolate shared 98.7\% 16S rRNA gene sequence identity with Nautilia profundicola strain $\mathrm{AmH}^{\mathrm{T}}$ (Smith et al., 2008), 97.2\% 16S rRNA gene sequence identity with Nautilia lithotrophica strain $525^{\mathrm{T}}$ (Miroshnichenko et al., 2002) and 97.4\% 16S rRNA gene sequence identity with strain Ex-18.2, a third isolate not formerly described (Campbell et al., 2001). These three closest relatives were all isolated from tubes of the worm Alvinella pompejana and belonged to the genus Nautilia. Otherwise, the novel isolate was most distantly related to members of the genera Lebetimonas and Caminibacter, sharing 91.9\% to $93.2 \%$ 16S rRNA gene sequence identity with representative species of these genera (Table 1). Based on the sequence similarity and phylogenetic analyses, the novel isolate could be assigned to the genus Nautilia. The level of 16S rDNA sequence 
dissimilarity with $N$. profundicola and $N$. lithotrophica suggests that the novel isolate belongs to a novel species (Stackebrandt and Ebers, 2006).

The phenotypic and genotypic properties of the novel isolate described herein generally met the minimal characteristics described for the order Nautiliales (Miroshnichenko et al., 2004). Indeed, strain PH1209 ${ }^{\mathrm{T}}$ is a marine thermophilic sulfur-reducing bacterium growing chemolithoautrophically from $\mathrm{H}_{2}$ oxidation. It unambiguously branches with other Nautiliales. Nevertheless, strain $\mathrm{PH} 1209^{\mathrm{T}}$ can be easily distinguished from other Nautiliales species in terms of a number of phylogenetic, genotypic and physiological features. These distinctive criteria are detailed in Table 1. In brief, in addition to the phylogenetic distance, the novel taxon differs from its closest relatives by its temperature, $\mathrm{NaCl}$ and $\mathrm{pH}$ ranges for growth. Its generation time under optimal growth condition is also slightly different from the ones of its relatives. Furthermore, differences in the utilization profiles of carbon sources, electron donors and electron acceptors are also observed. In contrast to its congeners N. lithotrophica and N. profundicola which are able to use formate as energy and carbon source, the novel isolate is unable. Finally, another distinctive criterion is the DNA G+C content. In conclusion, in view of all the above-mentioned distinctive features, we propose that the isolate $\mathrm{PH} 1209^{\mathrm{T}}$ should be assigned as the type strain of a novel species, for which the name Nautilia abyssi sp. nov. is proposed.

\section{Description of Nautilia abyssi sp. nov.}

Nautilia abyssi (a.bys'si. L. gen. n. abyssi, of an abyss, of the great deep).

Cells are Gram-negative motile rods, approximately $1.6 \mu \mathrm{m}$ in length and $0.4 \mu \mathrm{m}$ in width, with a single polar flagellum. Optimal growth occurs at $60^{\circ} \mathrm{C}$, with a growth range from 33 to $65^{\circ} \mathrm{C}$. The $\mathrm{pH}$ and $\mathrm{NaCl}$ ranges are 5.0-8.0 (optimum 6.0-6.5) and 2-4\% (w/v) (optimum, 3\% w/v NaCl), respectively. Growth occurs under strictly anaerobic conditions using $\mathrm{H}_{2}$ as an electron donor, elemental sulfur (or colloidal sulfur) as a terminal electron acceptor and $\mathrm{CO}_{2}$ as a carbon source. Yeast extract and peptone can be used as alternative carbon sources, but formate, acetate, methanol, lactate, propionate, fumarate, malate, citrate, pyruvate, glucose and glycogen can not. The following are not utilized as electron acceptors: L-cystine, thiosulfate, sulfate, sulfite, nitrate, nitrite, oxygen. The following are not used as electron donors: formate, acetate, methanol and yeast extract. Sensitive to $10 \mu \mathrm{g} \mathrm{ml}^{-1}$ of the following antibiotics: vancomycin, 
streptomycin, chloramphenicol, penicillin, ampicillin, tetracycline; sensitive to $25 \mu \mathrm{g} \mathrm{ml}^{-1}$ rifampicin and $50 \mu \mathrm{g} \mathrm{ml}{ }^{-1}$ kanamycin. Genomic DNA G+C content of the type strain $\mathrm{PH} 1209^{\mathrm{T}}$ is $35 \mathrm{~mol} \%$.

The type strain, PH1209 ${ }^{\mathrm{T}}$ (DSM $21157^{\mathrm{T}}$, JCM $15390^{\mathrm{T}}$ ) was isolated from the walls of an active deep-sea hydrothermal chimney colonized with alvinellid worms, on the East Pacific Rise $\left(103^{\circ} 56^{\prime} \mathrm{W}, 12^{\circ} 48^{\prime} \mathrm{N}\right)$. It is also available under request at the "Souchothèque de Bretagne" (catalogue LMBE) culture collection (http://www.ifremer.fr/souchotheque/).

\section{ACKNOWLEDGEMENTS}

We acknowledge Prof. J. P. Euzéby for support in the Latin etymologies of the species name. We thank the captain and crew of the NO L'Atalante, the pilots and support crew of the ROV Victor and N. Le Bris, Chief Scientist for helping us to collect deep-sea hydrothermal vent samples during the PHARE oceanographic cruise. We are grateful to the anonymous reviewers for their constructive comments about the manuscript. This work was financially supported by the Région Bretagne and the joined research unit UMR6197, linking the Université de Bretagne Occidentale to the Ifremer and the Centre National de la Recherche Scientifique.

\section{REFERENCES}

Alain, K., Querellou, J., Lesongeur, F., Pignet, P., Crassous, P., Raguénès, G., Cueff, V. \& Cambon-Bonavita, M.A. (2002). Caminibacter hydrogeniphilus gen. nov., sp. nov., a novel thermophilic, hydrogen-oxidizing bacterium isolated from an East Pacific Rise hydrothermal vent. Int J Syst Evol Microbiol 52, 1317-1323.

Alain, K., Zbinden, M., Le Bris, N., Lesongeur, F., Querellou, J., Gaill, F. \& Cambon-Bonavita, M. -A. (2004). Early steps in microbial colonization processes at deep-sea hydrothermal vents. Environ Microbiol 6, $227-241$.

Altschul, S., Gish, W., Miller, W., Myers, E. \& Lipman, D. (1990). Basic local alignment search tool. J Mol Biol 215, 403-410.

Campbell, B. J., Jeanthon, C., Kostka, J., Luther III, G. W. \& Cary, C. (2001). Growth and phylogenetic properties of novel bacteria belonging to the epsilon subdivision of the Proteobacteria enriched from Alvinella pompejana and deep-sea hydrothermal vents. Appl Environ Microbiol 67, 4566-4572.

Campbell, B. J., Summers Engel, A., Porter, M. L. \& Takai, K. (2006). The versatile $\varepsilon$-proteobacteria: key players in sulphidic habitats. Nature 4, 458-468.

Cord-Ruwisch, R. (1985). A quick method for the determination of dissolved and precipitated sulfides in cultures of sulphate-reducing bacteria. J Microbiol Methods 4, 33-36. 
Felsenstein, J. (1981). Evolutionary trees from DNA sequences: a maximum likelihood approach. J Mol Evol 17, 368376.

Felsenstein, J. (1985). Confidence limits on phylogenies: an approach using the bootstrap. Evol 30, 783-791.

Galtier, N., Gouy, M. \& Gautier, C. (1996). SEAVIEW and PHYLO_WIN: two graphic tools for sequence alignment and molecular phylogeny. CABIOS 12, 543-548.

Garrity, G. M., Bell, J. A. \& Lilburn, T. (2005). Class V. Epsilonproteobacteria class. nov. In Bergey's Manual of Systematic Bacteriology, $2^{\text {nd }}$ edn, vol. 2 (The Proteobacteria), part C (The Alpha-, Beta-, Delta-, and Epsilonproteobacteria), p.1145. Edited by D. J. Brenner, N. R. Krieg, J. T. Staley \& G. M. Garrity. New York: Springer.

Garrity, G. M., Bell, J. A. \& Lilburn, T. (2005). Order I. Campylobacterales ord. nov. In Bergey’s Manual of Systematic Bacteriology, $2^{\text {nd }}$ edn, vol. 2 (The Proteobacteria), part C (The Alpha-, Beta-, Delta-, and Epsilonproteobacteria), p.1145. Edited by D. J. Brenner, N. R. Krieg, J. T. Staley \& G. M. Garrity. New York: Springer.

Inagaki, F., Takai, K., Kobayashi, H., Nealson, K.H. \& Horikoshi, K. (2003). Sulfurimonas autotrophica gen. nov., sp. nov., a novel sulfur-oxidizing $\varepsilon$-proteobacterium isolated from hydrothermal sediments in the Mid-Okinawa Trough. Int J Syst Evol Microbiol 53, 1801-1805.

Longnecker, K. \& Reysenbach, A.-L. (2001). Expansion of the geographic distribution of a novel lineage of epsilonProteobacteria to a hydrothermal vent site on the Southern East Pacific Rise. FEMS Microbiol Ecol 35, $287-293$.

Lopez-Garcia, P., Gaill, F. \& Moreira, D. (2002). Wide bacterial diversity associated with tubes of the vent worm Riftia pachyptila. Environ Microbiol 4, 204-215.

Mesbah, M., Premachandran, U. \& Whitman, W. (1989). Precise measurement of the G+C content of deoxyribonucleic acid by high performance liquid chromatography. Int J Syst Bacteriol 39, 159-167.

Miroshnichenko, M.L., Kostrikina, N.A., L'Haridon, S., Jeanthon, C., Hippe, H., Stackebrandt, E. \& BonchOsmolovskaya, E.A. (2002). Nautilia lithotrophica gen. nov., sp. nov., a thermophilic sulfur-reducing $\varepsilon$ proteobacterium isolated from a deep-sea hydrothermal vent. Int J Syst Evol Microbiol 52, 1299-1304.

Miroshnichenko, M.L., L'Haridon, S., Schumann, P., Spring, S., Bonch-Osmolovskaya, E.A., Jeanthon, C. \& Stackebrandt, E. (2004). Caminibacter profundus sp. nov., a novel thermophile of Nautiliales ord. nov. within the class 'Epsilonproteobacteria' isolated from a deep-sea hydrothermal vent. Int J Syst Evol Microbiol 54, 41-45.

Moussard, H., Corre, E., Cambon-Bonavita, M.-A., Fouquet, Y. \& Jeanthon, C. (2006). Novel uncultured Epsilonproteobacteria dominate a filamentous sulphur mat from the $13^{\circ} \mathrm{N}$ hydrothermal vent field, East Pacific Rise. 
Polz, M.F. \& Cavanaugh, C.M. (1995). Dominance of one bacterial phylotype at a Mid-Atlantic Ridge hydrothermal vent site. Proc Natl Acad Sci USA 92, 7232-7236.

Saitou, N. \& Nei, M. (1987). The neighbour-joining method: a new method for reconstructing phylogenetic trees. Mol Biol Evol 4, 406-425.

Smith, J. L., Campbell, B. J., Hanson, T. E., Zhang, C. L. \& Cary, S. C. (2008). Nautilia profundicola sp. nov., a thermophilic, sulfur-reducing epsilonproteobacterium from deep-sea hydrothermal vents. Int J Syst Evol Microbiol 58, 1598-1602.

Stackebrandt, E. \& Ebers, J. (2006). Taxonomic parameters revisited: tarnished gold standards. Microbiol Today $33: 152-155$.

Takai, K., Inagaki, F., Nakagawa, S., Hirayama, H., Nunoura, T., Sako, Y., Nealson, K.H. \& Horikoshi, K. (2003). Isolation and phylogenetic diversity of members of previously uncultivated $\varepsilon$-Proteobacteria in deep-sea hydrothermal fields. FEMS Microbiol Lett 218, 167-174.

Takai, K., Hirayama, H., Nakagawa, T., Suzuki, Y., Nealson, K.H., Horikoshi, K. (2005). Lebetimonas acidiphila gen. nov., sp. nov., a novel thermophilic, acidophilic, hydrogen-oxidizing chemolithoautotroph within the 'Epsilonproteobacteria', isolated from a deep-sea hydrothermal fumarole in the Mariana Arc. Int J Syst Evol Microbiol 55, 183-189.

Takai, K., Suzuki, M., Nakagawa, S., Miyazaki, M., Suzuki, Y., Inagaki, F. \& Horikoshi, K. (2006). Sulfurimonas paralvinellae sp. nov., a novel mesophilic, hydrogen- and sulfur-oxidizing chemolithoautotroph within the Epsilonproteobacteria isolated from a deep-sea hydrothermal vent polychaete nest, reclassification of Thiomicrospira denitrificans comb. nov. and emended description of the genus Sulfurimonas. Int J Syst Evol Microbiol 56, $1725-1733$. Thompson, J.D., Gibson, T.J., Plewniak, F., Jeanmougin, F. \& Higgins, D.G. (1997). The ClustalX windows interface: flexible strategies for multiple sequence alignment aided by quality analysis tools. Nucleic Acids Res $\mathbf{2 4}$, $4876-4882$.

Voordeckers, J.W., Starovoytov, V. \& Vetriani, C. (2005). Caminibacter mediatlanticus sp. nov., a thermophilic, chemolithoautotrophic, nitrate-ammonifying bacterium isolated from a deep-sea hydrothermal vent on the Mid-Atlantic Ridge. Int J Syst Evol Microbiol 55, 773-779. 
TABLES and FIGURES
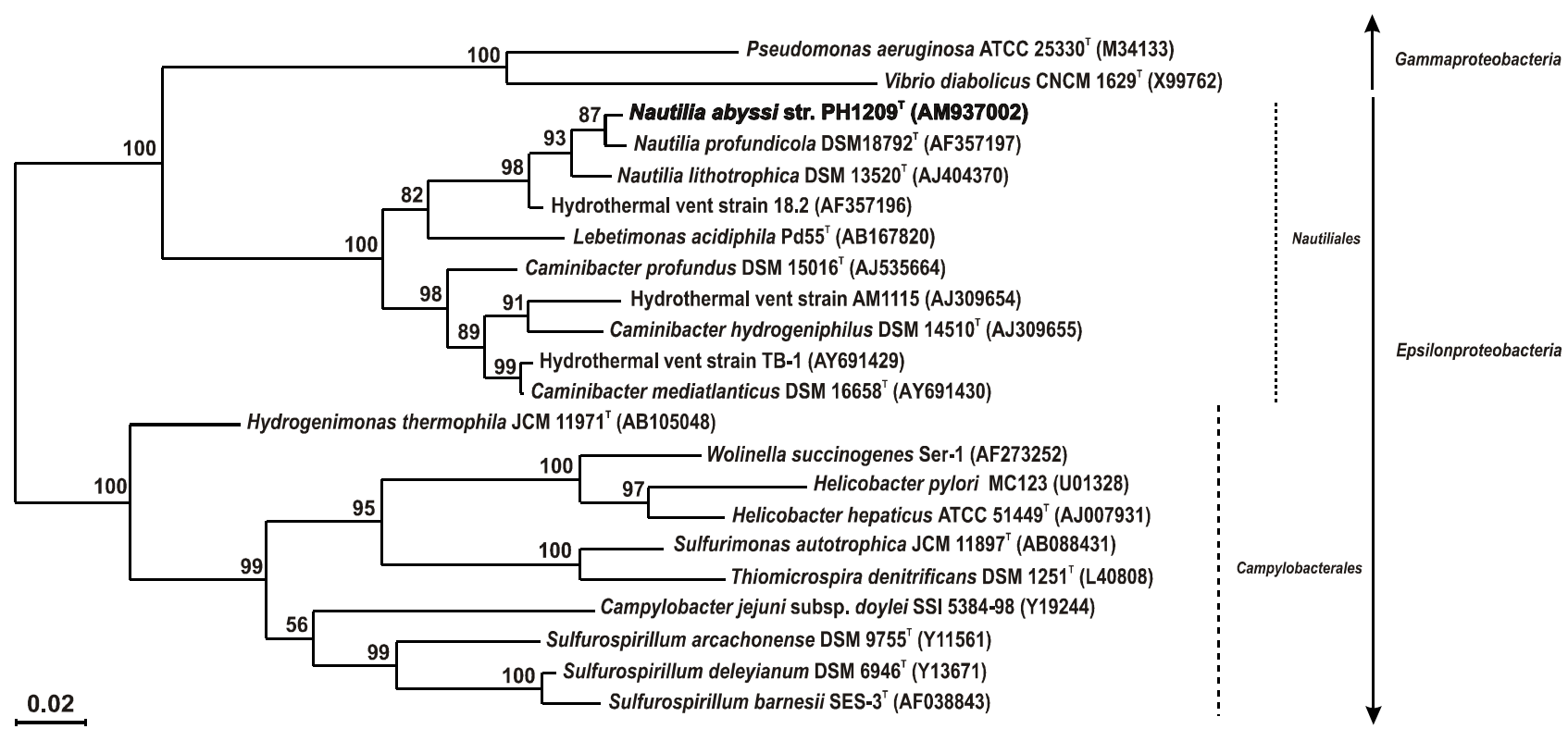

Fig. 1. Phylogenetic tree based on 16S rRNA gene sequences of strain $\mathrm{PH}_{1209^{\mathrm{T}}}$ and representative members of related genera within the class Epsilonproteobacteria. Sequence data of reference strains were obtained from the GenBank/EMBL and/or RDP databases. Two species from the Gammaproteobacteria were chosen as outgroups. Accession numbers are indicated in parentheses. The topology shown corresponds to an unrooted tree obtained by the maximum likelihood algorithm, established using the PHYLIP package. Bootstrap values (from 100 replicates) are indicated at the branch nodes. The positioning of the novel isolate was confirmed by the neighbour-joining method. The scale bar indicates $2 \mathrm{nt}$ substitutions per $100 \mathrm{nt}$.

Table 1. Characteristics differentiating strain $\mathrm{PH}_{1209^{\mathrm{T}}}$ from related species of the order Nautiliales. Species: 1, Nautilia abyssi PH1209 ${ }^{\mathrm{T}}$ (this study); 2, Nautilia profundicola $\mathrm{AmH}^{\mathrm{T}}$ (Smith et al., 2008); 3,

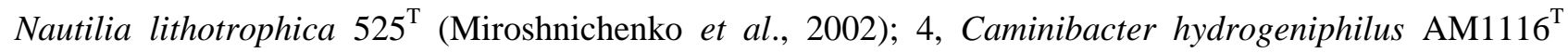
(Alain et al., 2002); 5, Caminibacter profundus $\mathrm{CR}^{\mathrm{T}}$ (Miroshnichenko et al., 2004); 6, Caminibacter mediatlanticus $\mathrm{TB}-2^{\mathrm{T}}$ (Voordeckers et al., 2005); 7, Lebetimonas acidiphila $\mathrm{Pd} 55^{\mathrm{T}}$ (Takai et al., 2005). Legend: +, positive; -, negative; w, weak growth; ND, not determined. The percentage of 16S rRNA gene sequence identity is calculated in reference to the $16 \mathrm{~S}$ rRNA gene sequence of the novel isolate $\mathrm{PH} 1209^{\mathrm{T}}$. 


\begin{tabular}{|c|c|c|c|c|c|c|c|}
\hline Characteristic & 1 & 2 & 3 & 4 & 5 & 6 & 7 \\
\hline Temperature range for growth $\left({ }^{\circ} \mathrm{C}\right)$ [optimum] & $33-65[60]$ & $30-55[40]$ & $37-68[53]$ & $\begin{array}{c}50-70 \\
{[60]}\end{array}$ & $45-65[55]$ & $\begin{array}{c}45-70 \\
{[55]}\end{array}$ & $\begin{array}{c}30-68 \\
{[50]}\end{array}$ \\
\hline pH range for growth & $5.0-8.0$ & $6.0-9.0$ & 6.4-7.4 & $5.5-7.5$ & $6.5-7.4$ & $4.5-7.5$ & $4.2-7.0$ \\
\hline $\mathrm{NaCl}$ concentration range for growth $(\%)$ & $2.0-4.0$ & $2.0-5.0$ & $0.8-5.0$ & $1.0-4.0$ & $0.5-5.0$ & $1.0-4.0$ & $0.6-5.0$ \\
\hline [optimum] & {$[3.0]$} & {$[3.0]$} & {$[3.0]$} & {$[2.0-2.5]$} & {$[3.0]$} & {$[3.0]$} & {$[2.0]$} \\
\hline Generation time (min.) & 120 & 360 & 140 & 90 & 40 & 50 & 120 \\
\hline Complex organic substrates & + & ND & ND & + & ND & ND & - \\
\hline \multicolumn{8}{|l|}{ Utilization of electron donor other than $\mathrm{H}_{2}$} \\
\hline Formate & - & + & + & - & - & - & - \\
\hline \multicolumn{8}{|l|}{ Utilization of electron acceptor other than $S^{\circ}$} \\
\hline Oxygen & - & - & - & - & + & - & - \\
\hline Nitrate & - & - & - & + & + & + & - \\
\hline
\end{tabular}




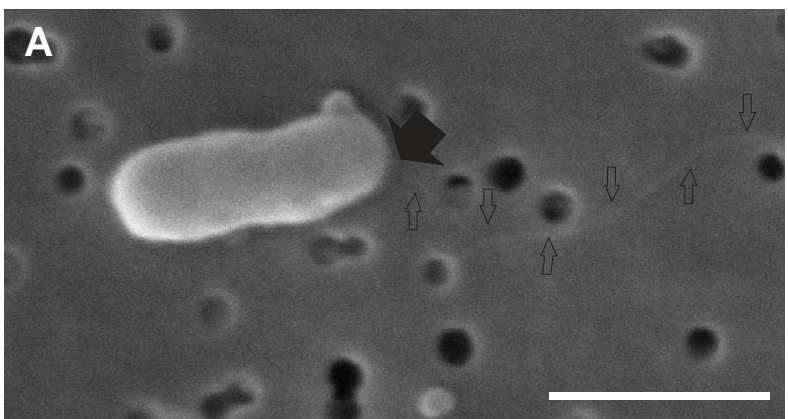

B

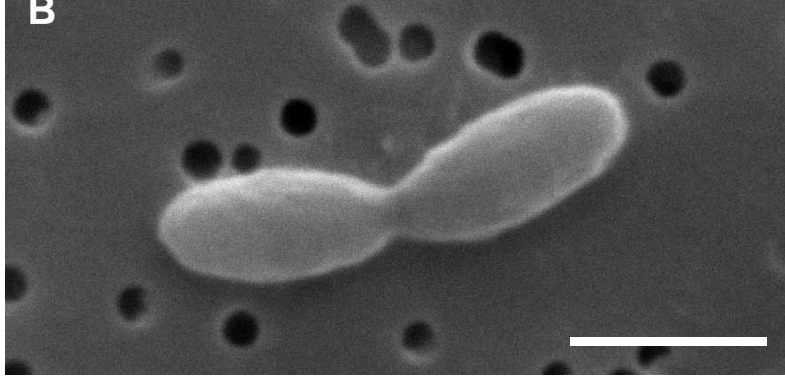

313 Fig. S1. Scanning electron micrographs of cells of strain $\mathbf{P H 1 2 0 9}^{\mathrm{T}}$ in the mid-exponential phase of 314 growth, showing the polar flagellum (A) and division by constriction (B). Bar, $1.0 \mu \mathrm{m}$. 


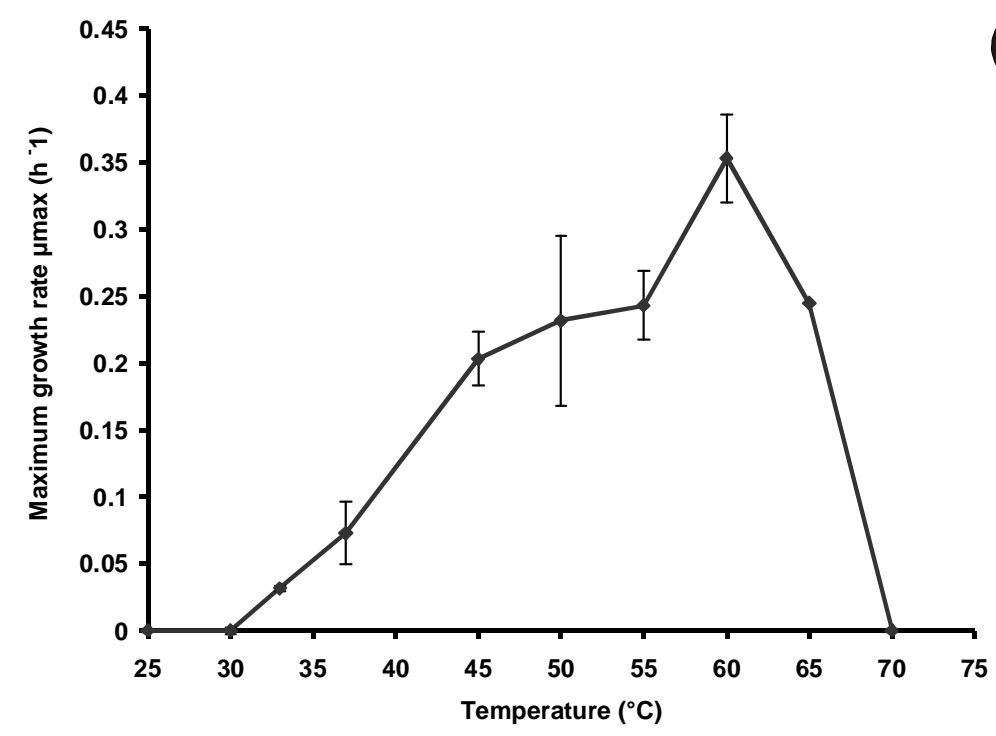

(A)
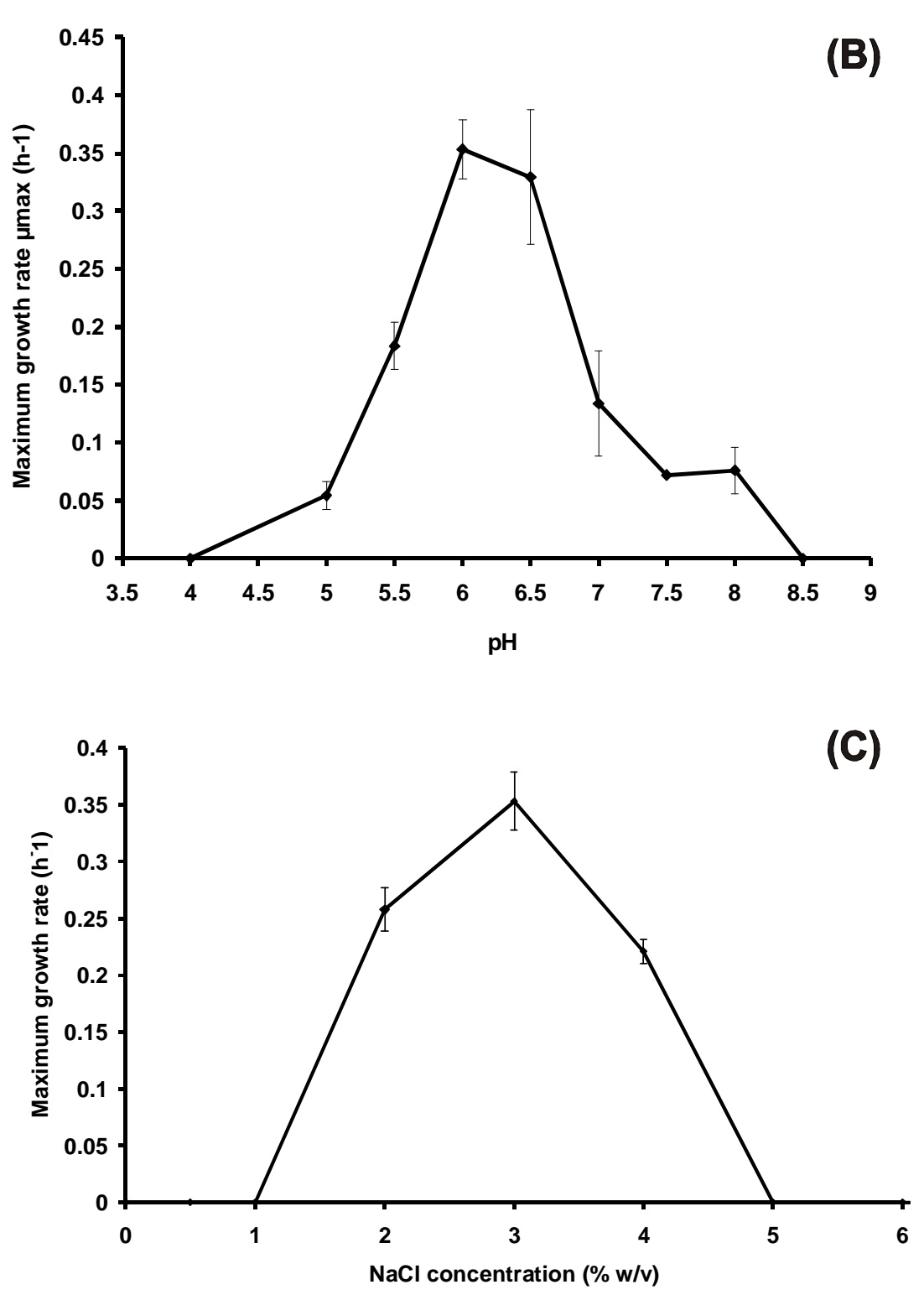
317 Fig. S2. Maximum growth rate $\left(\mathrm{h}^{-1}\right)$ of strain $\mathbf{P H 1 2 0 9}^{\mathrm{T}}$ (Nautilia abyssi sp. nov.) at varying 318 temperatures (A), $\mathbf{p H}(\mathrm{B})$ and $\mathrm{NaCl}$ concentrations (C). Bars indicate confidence intervals. 